\title{
Advanced Oxidation Processes to the Remediation of Liquid Residue from the Thermal Treatment of Oily Sludge
}

\author{
Graziela S. Costa, ${ }^{a, b}$ Christine A. Althoff, Jéssica T. Schneider ${ }^{a}$ and \\ Patricio Peralta-Zamora ${ }^{(*, a}$ \\ ${ }^{a}$ Departamento de Química, Universidade Federal do Paraná, CP 19081, \\ 81531-980 Curitiba-PR, Brazil
}

${ }^{b}$ Albrecht Equipamentos Industriais Ltda., CP 7171, 89239-052 Joinville-SC, Brazil

\begin{abstract}
This work reports the remediation of a liquid residue derived from the thermal treatment of petrochemical residues by advanced oxidation processes. Firstly, degradation studies of phenol aqueous solutions by heterogeneous photocatalysis, Fenton, and photo-Fenton were conducted. Fenton processes showed a higher efficiency, mainly in the UVA photo-assisted mode $(94 \%$ in $3 \mathrm{~min}$ ), and henceforward it was chosen for the remediation of the residue. However, the high organic load of the raw residue $\left(6,000 \mathrm{mg} \mathrm{L}^{-1}\right.$ of chemical oxygen demand (COD)) limited the efficiency of the Fenton processes. Hence, the raw liquid residue was diluted with the scrubber residue, produced during the thermal treatment of the petrochemical residues, reducing the COD to values close to $2,000 \mathrm{mg} \mathrm{L}^{-1}$. The photo-Fenton treatment allowed the removal of approximately $95 \%$ of the COD load, decreasing the residual concentration of phenolic compounds from 213 to $0.5 \mathrm{mg} \mathrm{L}^{-1}$. At the same time, the concentration of BTEXs (benzene, toluene, ethylbenzene and xylene) were reduced to values lower than the limit of quantification (LOQ) of the chromatographic technique. Therefore, the photo-Fenton process is an efficient alternative to the remediation of residues with high complexity and with high COD values, like the ones obtained in the petrochemical industry.
\end{abstract}

Keywords: petrochemical residue, thermal treatment, Fenton, phenols, BTEXs

\section{Introduction}

In the context of the petroleum industry, which has a well-known pollutant potential, oily sludge represents a serious environmental problem. ${ }^{1-3}$ The oily sludge is a stable $\mathrm{W} / \mathrm{O}$ (water in oil) emulsion of water, solids and petroleum hydrocarbons generated in the petroleum refining process during the dissolved air flotation process. ${ }^{2}$ According to the literature ${ }^{4}$ it is constituted by water (90-99 wt.\%), crude oil waste (0.5-3 wt.\%) and mineral particles (0.2-7 wt.\%). The organic composition of oily sludge varies with the variety of crude oils. However, it is estimated that the most common organic species are alkanes, cycloalkanes, benzene, toluene, ethyl-benzene, xylenes, and lower concentrations of phenolic compounds and polycyclic aromatic hydrocarbons. ${ }^{5}$

Due to the mutagenic and teratogenic nature of many hydrocarbons, oily sludge has been considered a priority environmental pollutant by the US Environmental

*e-mail: zamora@ufpr.br
Protection Agency (US EPA). ${ }^{6}$ Therefore, the effective remediation of oily sludge and the safe disposal of the wastes have become a worldwide problem, ${ }^{4}$ obligatory for oil industries. ${ }^{6}$

A large number of methods have been proposed to treat oily sludge, ${ }^{4}$ including chemical systems based on solvent extraction, ${ }^{7}$ physical systems based on filtration ${ }^{8}$ or centrifugation, ${ }^{9}$ and biological methods based on bioaugmentation strategies. ${ }^{10}$ Furthermore, the treatment of oily sludge by pyrolysis in circulating fluidized beds has also been described. ${ }^{11}$ The thermal decomposition of the waste at temperatures between 500 and $1000{ }^{\circ} \mathrm{C}$ under inert atmosphere usually leads to the formation of low molecular weight hydrocarbons, which can be recovered as condensate. ${ }^{4}$

Considering this scenario, the companies Albrecht (Joinville, Brazil) and Petrobras S.A. (Rio de Janeiro, Brazil) developed a multiphase waste thermal treatment unit called TELAB K200 (patent registry No. PI 0400305-5). ${ }^{12}$ In this pilot equipment, oily sludge is treated by thermal processes of evaporation, desorption and pyrolysis, 
resulting in the breakdown of heavy molecules, such as resins and asphaltenes. Despite the waste thermal treatment, a liquid residue containing high concentration of phenolic compounds is generated, implying the need for an additional treatment before final disposal.

The toxic effect produced by phenolic compounds has been extensively reported elsewhere. ${ }^{13,14}$ In general, toxic levels ranging between 10-24 and 9-25 $\mathrm{mg} \mathrm{L}^{-1}$ are accepted for human and fish, respectively. ${ }^{15}$ Therefore, the US EPA ${ }^{15}$ has set the maximum phenol level in wastewater in $0.1 \mathrm{mg} \mathrm{L}^{-1}$.

Aromatic compounds in wastewater are recalcitrant and toxic to microorganisms in conventional biological treatments. ${ }^{16,17}$ Many methods have been reported for the treatment of phenolic waste water including air oxidation, ${ }^{18}$ adsorption, ${ }^{19}$ and halogenation processes. ${ }^{20}$ Regarding chemical treatments, advanced oxidation processes (AOP) occupy a prominent place, mainly due to their high mineralization capacity toward several biorefractory organic compounds, ${ }^{21,22}$ typically with less energy requirements. ${ }^{23}$ Several studies have reported efficient degradation of phenol by heterogeneous photocatalysis assisted by $\mathrm{TiO}_{2}{ }^{24,25}$ and $\mathrm{ZnO},{ }^{26} \mathrm{Fenton}^{27}$ and photo-Fenton processes. $^{28}$

In the present work, the potentiality of advanced oxidation processes (Fenton, photo-Fenton, $\mathrm{TiO}_{2} / \mathrm{UV}$ and $\mathrm{ZnO} / \mathrm{UV}$ ) was investigated, regarding the degradation of phenolic compounds in a liquid residue from the thermal treatment of petrochemical residues (oily sludge).

\section{Experimental}

\section{Chemicals}

Phenol (Synth, 99\% purity) was used to prepare the synthetic effluent. Titanium dioxide Degussa P-25 (approximately $80 \%$ anatase and 20\% rutile, surface area $50 \mathrm{~m}^{2} \mathrm{~g}^{-1}$ ) and Nuclear zinc oxide (surface area $4 \mathrm{~m}^{2} \mathrm{~g}^{-1}$ ) were used in heterogeneous photocatalytic processes. $\mathrm{FeSO}_{4} \cdot 7 \mathrm{H}_{2} \mathrm{O}$ and $\mathrm{H}_{2} \mathrm{O}_{2}$ (Fenton reactants) of analytical grade were purchased from Isofar and Synth, respectively. High-performance liquid chromatography (HPLC)-grade acetonitrile (J.T.Baker) was used in the chromatographic analyses. All other chemicals used were of analytical grade.

\section{Residue source}

A generic representation of the transportable plant for thermal treatment of oily sludge (TELAB) is shown in Figure 1. The system consists of a tubular reactor equipped with a fixed-pitch screw conveyor, where the residue is heated under reduced pressure in the presence of nitrogen. The reactor has four heating zones. Zone 1 (to $100{ }^{\circ} \mathrm{C}$ ) induces the evaporation of free and emulsified water and light hydrocarbons. Zone 2 (to $250^{\circ} \mathrm{C}$ ) induces the thermal desorption, while zone 3 (to $450^{\circ} \mathrm{C}$ ) promotes a mild pyrolysis with partial conversion of the heavier fraction into compounds of lower molecular weight. Zone 4 (to $900^{\circ} \mathrm{C}$ ) corresponds to the muffle furnace. The gas emerging from the four heating zones are exhausted into a washing/cooling system that condensates water and releases petroleum hydrocarbons, while not condensable gases are treated in wet scrubbers prior to the release to the atmosphere (scrubber residue).

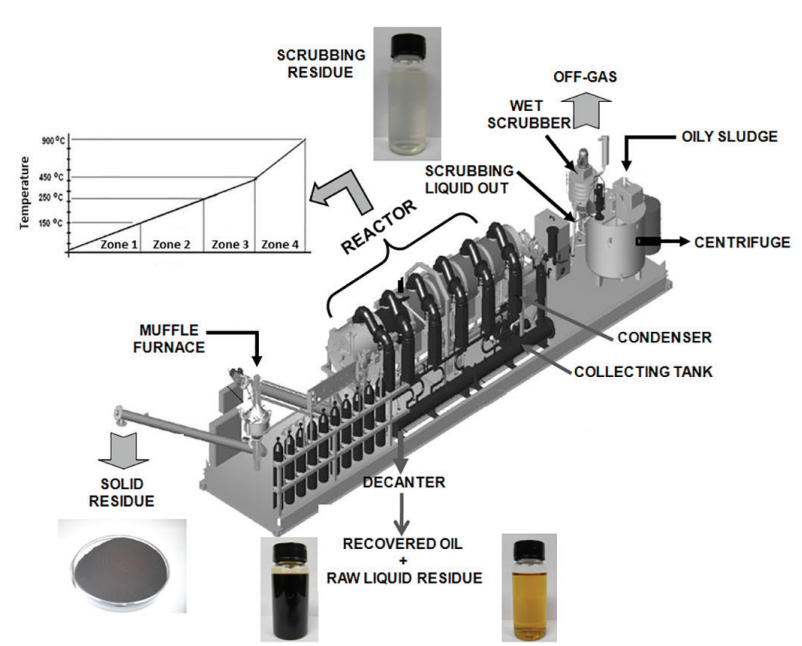

Figure 1. Representation of the multiphase wastes thermal treatment unit (TELAB) used in the treatment of oily sludge.

The condensed oil and the water are stored in collecting tanks and subsequently separated by decantation, obtaining the recovered oil and the raw liquid residue. After reaching $900{ }^{\circ} \mathrm{C}$, a solid residue is obtained in the muffle furnace, with the removal of the remaining organic compounds.

\section{Degradation procedure}

Degradation studies were carried out in a $250 \mathrm{~mL}$ bench photochemical reactor equipped with a water cooling system and a magnetic stirrer. The radiation was provided by a high-pressure mercury vapor lamp (125 W), which was inserted into the solution using a quartz (UVC) or Pyrex (UVA) bulb. The effect of photolysis on phenol degradation was studied in the presence of UVC and UVA radiation and absence of photocatalysts. Heterogeneous photocatalytic processes were performed in the presence of UVA radiation and $0.25 \mathrm{~g} \mathrm{~L}^{-1}$ of photocatalyst $\left(\mathrm{TiO}_{2}\right.$ or $\left.\mathrm{ZnO}\right)$. The studies were carried out with $200 \mathrm{~mL}$ of aqueous solution of phenol at $30 \mathrm{mg} \mathrm{L}^{-1}$, without adjustment of $\mathrm{pH}$. To evaluate 
the adsorption of phenol into the photocatalyst surface, experiments were carried out in the same conditions in the absence of radiation.

Fenton and photo-Fenton UVA processes were performed at $\mathrm{pH} 3$ with $200 \mathrm{~mL}$ of aqueous solution, containing phenol at $10 \mathrm{mg} \mathrm{L}^{-1}$ and Fenton reactants (10 mg L $\mathrm{m} \mathrm{Fe}^{2+}$ and $100 \mathrm{mg} \mathrm{L}^{-1} \mathrm{H}_{2} \mathrm{O}_{2}$ ). Due to the rapid consumption of hydrogen peroxide observed in the treatment of the liquid residue, the Fenton process was applied with multiple additions of $\mathrm{H}_{2} \mathrm{O}_{2}\left(200 \mathrm{mg} \mathrm{L}^{-1}\right.$ every $20 \mathrm{~min}$ ). Fenton reaction was interrupted by the addition of $\mathrm{NaHSO}_{3}$ in the final concentration of $40 \% \mathrm{~m} / \mathrm{v}$.

Aliquots were collected at regular time intervals up to $120 \mathrm{~min}$, and filtered through a $0.45 \mu \mathrm{m}$ cellulose ester membrane filter (Whatman ${ }^{\circledR}$ Schleicher \& Schuell ${ }^{\circledR}$ ) before spectrophotometric and HPLC analyses.

\section{Analytical control}

The degradation of phenol was preliminary monitored by UV-Vis spectroscopy in a Varian Cary-50 spectrophotometer, by measuring the absorbance at $270 \mathrm{~nm}$ and the spectral area integrated between 200 and $350 \mathrm{~nm}$. Phenol and its byproducts were determined with liquid chromatography (HPLC) using water and acetonitrile as solvents, a C18 column and a diode-array detector, as priorly determined by Stets et al. ${ }^{29}$

The chemical oxygen demand (COD) was measured with UV-Vis spectrophotometry, according to the APHA 5220D Standard Method. ${ }^{30}$ Calibration curves were elaborated with standard potassium biphthalate for a COD level ranging from 100 to $800 \mathrm{mg} \mathrm{O}_{2} \mathrm{~L}^{-1}$. The determination of total phenols was carried out using the Folin-Ciocalteu method, according to the APHA 5550 Standard Method..$^{30}$ Calibration curves were elaborated with gallic acid in the concentration range between 1 and $100 \mathrm{mg} \mathrm{L}^{-1}$. The phenolic content (TPh) was expressed in $\mathrm{mg} \mathrm{L}^{-1}$ of equivalent gallic acid. Residual $\mathrm{Fe}^{\Pi \mathrm{I}}$ and hydrogen peroxide were monitored UV-Vis spectrophotometry, using methods based on the reaction with $o$-phenanthroline and metavanadate, respectively.

The BTEXs' (benzene, toluene, ethylbenzene and xylene) analysis was conducted in the TASQA laboratory (Paulínia, SP, Brazil) using gas chromatography, according to the US EPA 8260B. ${ }^{31}$ The BTEXs were determined with static headspace extraction followed by gas chromatography-mass spectrometry (GC-MS). The analysis of phenolic compounds was conducted in the TASQA laboratory (Paulínia, SP, Brazil) by gas chromatography-mass spectrometry (GC-MS), according to the US EPA 8270D.32 The phenolic compounds were extracted from the liquid petroleum residue using a method of liquid-liquid extraction with dichloromethane, according to the US EPA 3510C. . $^{33}$

The evaluation of the acute toxicity of the liquid petroleum residue was carried out in the Laboprime laboratory (Timbó, SC, Brazil). The toxicity tests were applied to the diluted residue before and after the treatment with the UVA photo-Fenton process. The microcrustacean Daphnia magna and the bacteria Vibrio fischeri were the toxicity bioindicators used in these tests. The methods used for the evaluation of the acute toxicity were the ABNT NBR $12713^{34}$ for Daphnia magna, and ABNT NBR 15411-335 for Vibrio fischeri.

\section{Results and Discussion}

\section{Characterization of raw liquid residue}

The oily sludge treatment produces four main residues: a solid fraction, and three liquid fractions (an oily fraction and two aqueous fractions), as shown in Figure 1. The present study aims to treat the condensed aqueous fraction from the decanter. A yellow to brown color and an offensive odor characterizes this residue, named raw liquid residue.

Since the composition of industrial residues typically varies, the raw liquid residue was firstly characterized. The main components of this residue are presented in Table 1. The high concentration of phenolic compounds (213 $\mathrm{mg} \mathrm{L}^{-1}$ ) indicates that after the treatment of the oily sludge these compounds stay in the aqueous phase due to their water solubility. ${ }^{36}$ The raw liquid residue exhibited acute toxicity (154 and 4,096), high concentration of ammoniacal nitrogen (257 $\left.\mathrm{mg} \mathrm{L}^{-1}\right)$, COD $\left(6,300 \mathrm{mg} \mathrm{L}^{-1}\right)$, biological oxygen demand (BOD, 3,134 $\mathrm{mg} \mathrm{L}^{-1}$ ), and oils and greases $\left(73.6 \mathrm{mg} \mathrm{L}^{-1}\right)$. These parameters were in disagreement with the standards ${ }^{37}$ established by the Brazilian legislation governing the discharge of effluents.

It is important to emphasize that the relatively high value of the BOD/COD ratio (ca. 0.5) suggests the feasibility of biological treatments, which represents an interesting preliminary treatment alternative.

Another relevant residue treated herein comes from the gas washing system. It was used for dilution of the raw liquid residue before the treatment. The scrubber residue is a turbid liquid characterized by a high COD $\left(845 \mathrm{mg} \mathrm{L}^{-1}\right)$ and a low concentration of phenolic species $\left(4.23 \mathrm{mg} \mathrm{L}^{-1}\right)$. The concentrations of BTEXs and phenolic compounds of the diluted residue are presented in Table 2. Despite the dilution, the phenolic compounds concentration stayed high and likewise the BTEXs, which are mainly represented by the extremely high concentration of toluene. Due to its 
Table 1. Main characteristics of the raw liquid residue

\begin{tabular}{|c|c|c|}
\hline Parameter & Value & Method \\
\hline Chemical oxygen demand (COD) / $\left(\mathrm{mg} \mathrm{L}^{-1}\right)$ & 6,300 & APHA $5220 D^{30}$ \\
\hline Total organic carbon $(\mathrm{TOC}) /\left(\mathrm{mg} \mathrm{L}^{-1}\right)$ & 1,570 & APHA $5310 B^{30}$ \\
\hline Biological oxygen demand (BOD) / (mg L $\left.{ }^{-1}\right)$ & 3,134 & APHA $5210 B^{30}$ \\
\hline Acute toxicity with Daphnia magna / DFa & 154 & ABNT NBR 12713:200934 \\
\hline Acute toxicity with Vibrio fischeri / $\mathrm{DF}^{\mathrm{a}}$ & 4,096 & ABNT NBR 15411-3:201235 \\
\hline Phenols / (mg L-1) & 213 & APHA $5550 B^{30}$ \\
\hline Volatile organic compounds (VOCs) / $\left(\mu \mathrm{g} \mathrm{L}^{-1}\right)$ & 2,181 & US EPA $8260 B^{31}$ \\
\hline Total ammonia nitrogen / $\left(\mathrm{mg} \mathrm{L}^{-1}\right)$ & 257 & APHA $4500-\mathrm{NH}_{3} \mathrm{E}^{30}$ \\
\hline $\mathrm{pH}$ & 7.38 & APHA $4500-\mathrm{H}^{+} \mathrm{B}^{30}$ \\
\hline Oils and greases / $\left(\mathrm{mg} \mathrm{L}^{-1}\right)$ & 73.6 & APHA 5520B ${ }^{30}$ \\
\hline
\end{tabular}

aDilution factor.

complexity, to reach the standards required by the current environmental legislation, ${ }^{37}$ this residue needs an efficient treatment before its disposal in the receiving body.

Table 2. BTEXs and phenols content before and after photo-Fenton treatment of the diluted residue

\begin{tabular}{lccc}
\hline Parameter & $\begin{array}{c}\text { Diluted residue / } \\
\left(\mu \mathrm{g} \mathrm{L}^{-1}\right)\end{array}$ & $\begin{array}{c}\text { Treated residue / } \\
\left(\mu \mathrm{g} \mathrm{L}^{-1}\right)\end{array}$ & MAV $^{\mathrm{a}}$ \\
\hline BTEXs & $65.4 \pm 25.2$ & $<2$ & 1200 \\
Benzene & $4577 \pm 1705$ & $<4$ & 1200 \\
Toluene & $25.4 \pm 12.8$ & $<2$ & 840 \\
Ethylbenzene & $31.1 \pm 12.4$ & $<2$ & 1600 \\
Xylene & & & 500 \\
Phenols & 99.7 & $<0.1$ & - \\
Phenol & $6.24 \pm 2.18$ & $<0.25$ & - \\
2-Methylphenol & $135 \pm 33.6$ & $<0.25$ & - \\
3-Methylphenol & $135 \pm 33.6$ & $<0.25$ & - \\
4-Methylphenol & &
\end{tabular}

${ }^{a}$ Maximum allowed value according to the Brazilian legislation. ${ }^{37}$

\section{Preliminary studies on phenol degradation}

Taking into account that the raw liquid residue has a high content of phenolic species, photolysis (UVA and UVC), heterogeneous photocatalysis $\left(\mathrm{TiO}_{2} / \mathrm{UVA}\right.$ and $\mathrm{ZnO} / \mathrm{UVA}$ ), Fenton, and photo-Fenton processes were preliminarily evaluated with phenol aqueous solutions. The main results of the treatments are briefly illustrated in Figure 2.

\section{Photolysis}

It is well known that photo-assisted processes can promote the degradation of substrates by concomitant processes, including UV photolysis. Therefore, the isolated effect of the radiation was evaluated using the conditions previously detailed.

UVA photolysis does not cause a significant effect on the spectroscopic signal of phenol, implying in a lower phenol degradation, as also observed by Chun et al. ${ }^{38}$ On the other hand, UVC irradiation leads to a significant increase in the signal throughout the monitored spectral region (200-350 nm), maintained until $120 \mathrm{~min}$ of treatment. The chromatographic analysis showed a rapid phenol degradation. This observation is in accordance with Chun et al. ${ }^{38}$ work. These authors have found that phenol is rapidly degraded by UVC photolysis, producing polymeric forms that remain for long treatment times. Based on these preliminary studies, further photo-assisted experiments were carried out in the absence of UVC radiation, by protecting the mercury lamp with a Pyrex glass jacket.

\section{Heterogeneous photocatalysis ( $\mathrm{TiO}_{2} / \mathrm{UVA}$ and $\mathrm{ZnO} / \mathrm{UVA}$ )}

The adsorption of the substrate on the photocatalyst has a significant role in the heterogeneous photocatalysis since it is believed that this is the first step of the process. The differentiation between degradation and adsorption is also important in these studies. Thus, the phenol adsorption was firstly evaluated and was shown to be negligible under the evaluated conditions ( $4.5 \%$ for $\mathrm{TiO}_{2}$ and $8 \%$ for $\mathrm{ZnO}$ ). Therefore, it can be disregarded in degradation studies. Similar results were reported in the literature. ${ }^{39-41}$

In photocatalytic processes mediated by $\mathrm{TiO}_{2}$, few changes were observed in the spectral profile, represented by an increase in the absorption signal in the monitored region followed by a slight decrease in posterior reaction times. Based on this observation and on a similar behavior exhibited by the total phenolic content, it can be assumed that phenol degradation leads to the formation of phenolic 


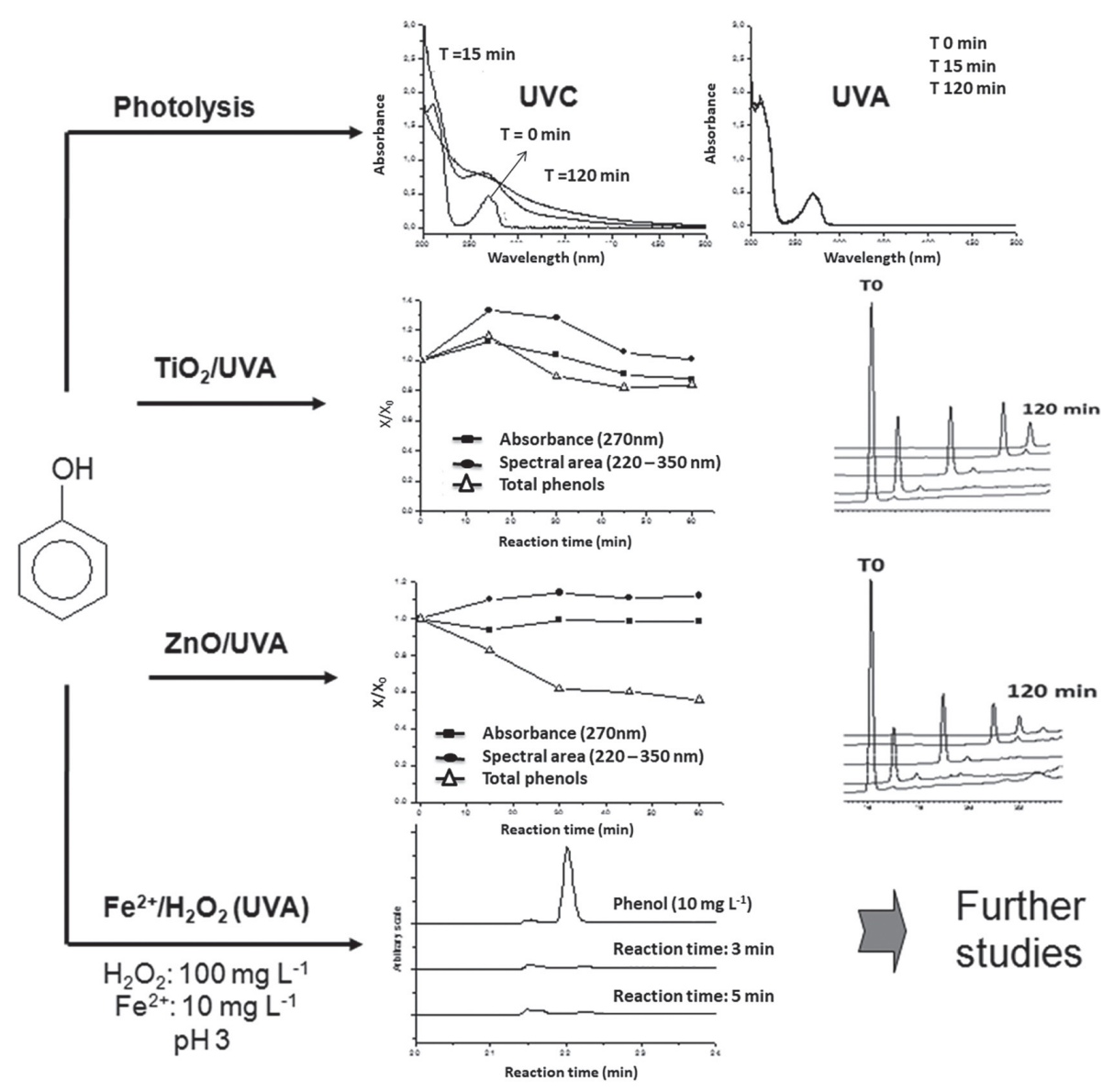

Figure 2. Summary of phenol degradation studies by advanced oxidative processes.

byproducts, as suggested before. Suzuki et al..$^{25}$ proposed that phenol is firstly hydroxylated leading to hydroquinone and catechol, which are further oxidized to $o$-benzoquinone and $p$-benzoquinone, respectively. Chromatographic analyses revealed a partial degradation of phenol $(88 \%$ in reaction time of $120 \mathrm{~min}$ ), and the formation of intermediates (hydroquinone, resorcinol, catechol and $p$-benzoquinone) remaining until the highest assessed reaction time (120 $\mathrm{min})$, confirming the non-mineralization of the substrate.

Similar results were observed in the presence of $\mathrm{ZnO}$. Considering the chromatographic peak areas, $\mathrm{TiO}_{2}$ has a slightly more favorable degradation, 88 against $77 \%$ of $\mathrm{ZnO}$ in 120 min of reaction time. In contrast, $\mathrm{ZnO}$ shows a lower total phenolic species. In the $\mathrm{ZnO} / \mathrm{UVA}$, the formed intermediates also remaining until $120 \mathrm{~min}$. It is important here that the degradation efficiency of both, ZnO/UVA and $\mathrm{TiO}_{2} / \mathrm{UVA}$, is not yet satisfactory and they present low mineralization capacity.

\section{Fenton and photo-Fenton processes}

Considering the chromatographic characterization, phenol showed a fast degradation, which allowed its almost complete removal (94\%) in reaction times of $3 \mathrm{~min}$ (Figure 3). The high activity of Fenton process in the first reaction times is accompanied by the consumption of $\mathrm{Fe}^{2+}$ and $\mathrm{H}_{2} \mathrm{O}_{2}$, and their concentration decreased by half in 5 and $10 \mathrm{~min}$, respectively. The production of the transient species that characterizes the phenol degradation (e.g., catechol, hydroquinone, $p$-benzoquinone, etc.) was not observed, probably due to the low initial phenol concentration.

In the presence of UVA radiation (photo-Fenton process), the degradation capacity of Fenton systems is significantly improved, as a result of photoassisted $\mathrm{Fe}^{2+}$ regeneration and the concomitant generation of another equivalent of hydroxyl radical. ${ }^{23}$ However, as observed during the Fenton process, phenol is rapidly decomposed reaching residual concentration of approximately $2 \mathrm{mg} \mathrm{L}^{-1}$ (98\%) after $3 \mathrm{~min}$, and the transient species were not observed in $3 \mathrm{~min}$ of reaction (Figure 4), presumably because of the low phenol concentration, and the high efficiency of the process. Although the phenol degradation does not appear to improve, when compared with the Fenton process in absence of radiation, $\mathrm{Fe}^{2+}$ and $\mathrm{H}_{2} \mathrm{O}_{2}$ demonstrated a promising behavior. $\mathrm{Fe}^{2+}$ was quickly transformed into $\mathrm{Fe}^{3+}$ in the first 3 min of reaction, and then 


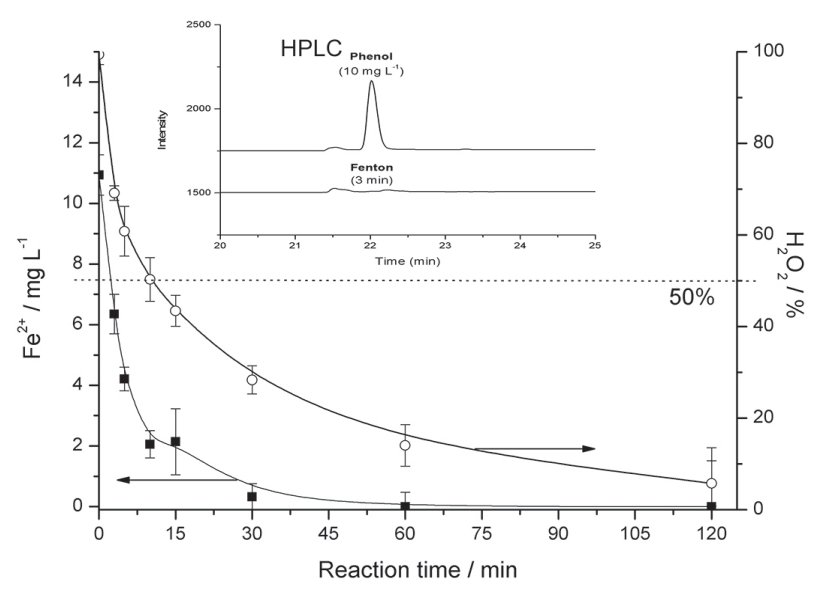

Figure 3. Variation of the $\mathrm{H}_{2} \mathrm{O}_{2}$ (open balls) and $\mathrm{Fe}^{2+}$ (closed squares) concentrations during the degradation of phenol by Fenton processes. Inset: chromatograms of the 0 and 3 min of the Fenton process.

was slowly regenerated. Hydrogen peroxide was rapidly decomposed. This is possibly correlated with a higher production of hydroxyl radical.

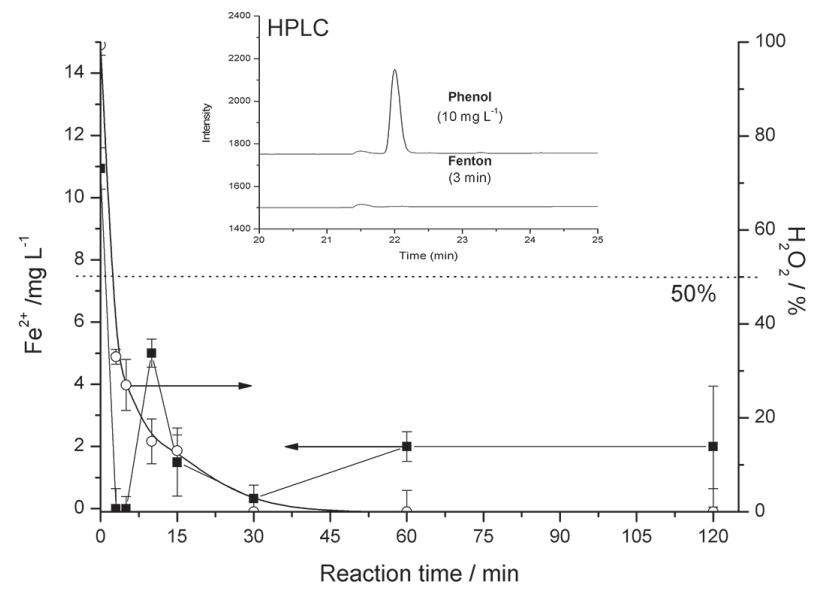

Figure 4. Variation of the $\mathrm{H}_{2} \mathrm{O}_{2}$ (open balls) and $\mathrm{Fe}^{2+}$ (closed squares) concentrations during the degradation of phenol by UVA photo-Fenton processes. Inset: chromatograms of the 0 and $3 \mathrm{~min}$ of the UVA photoFenton process.

\section{Comparison between the processes}

In this section, all treatments based on the phenol removing percentage (Figure 5) and the time of treatment are compared. UVA photolysis is the most inefficient treatment and UVC photolysis showed almost complete degradation of phenol in $120 \mathrm{~min}$ of reaction. Although this is a good removal percentage, it requires a long time, which impedes an industrial application. Most importantly, as discussed before ("Photolysis" sub-sub-section), UVC irradiation may lead to the production of polymeric species. ${ }^{38}$ Heterogeneous photocatalysis, $\mathrm{TiO}_{2} / \mathrm{UVA}$ and $\mathrm{ZnO} / \mathrm{UVA}$, presented 88 and $77 \%$ of phenol degradation in 120 min of reaction, respectively. In this case, the time is again a problem and the efficiency needs to be enhanced.
Fenton and photo-Fenton processes have achieved a complete degradation in $3 \mathrm{~min}$. Therefore, Fenton processes need a very short time and achieve better removing percentage. In a preliminary analysis, Fenton process seems to be the best treatment since it did not use radiation. However, as mentioned before ("Fenton and photo-Fenton processes" sub-sub-section), the photo-Fenton system produces more hydroxyl radical. Bearing in mind the complexity and the high COD values of the studied residue, a more aggressive treatment must be considered. Based on the exposed results, it becomes clear that the best choice to treat the raw liquid residue is the photo-Fenton process.

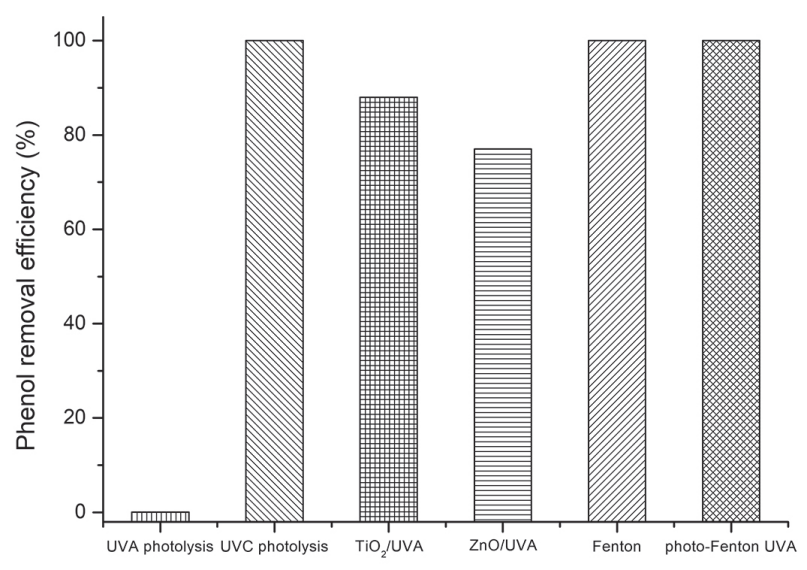

Figure 5. Comparison of the phenol degradation during the different treatments.

\section{Degradation of the raw liquid residue}

Considering the excellent preliminary results, the remediation study was initiated with Fenton process, using the previous experimental conditions $\left(\mathrm{Fe}^{2+}: 10 \mathrm{mg} \mathrm{L}^{-1}\right.$, $\mathrm{pH} 3.0, \mathrm{H}_{2} \mathrm{O}_{2}: 100 \mathrm{mg} \mathrm{L}^{-1}$ ), and the undiluted raw liquid residue. Promising results are found in the literature using the Fenton process. A petrochemical residue with $450 \mathrm{mg} \mathrm{L}^{-1}$ of initial COD presented approximately $80 \%$ of COD removed by Fenton process. ${ }^{42}$ Kakavandi and Babaei ${ }^{43}$ found satisfactory COD removal for a petrochemical residue (initial COD range 50-1000 $\mathrm{mg} \mathrm{L}^{-1}$ ) with the heterogeneous Fenton process. However, as shown in Figure 6, Fenton and photoFenton processes did not show satisfactory results. This may be explained considering the complex composition of the raw liquid residue, mainly due to the presence of high organic load $\left(6,000 \mathrm{mg} \mathrm{L}^{-1}\right.$ of COD, which essentially consists of phenolic compounds and petroleum hydrocarbon, e.g., BTEXs). Furthermore, the presence of ions in the residue can act as radical scavengers. ${ }^{44}$

Since advanced oxidation processes are not effective against organic loads of this magnitude, ${ }^{45}$ the raw liquid residue was pre-diluted to an organic load of about 


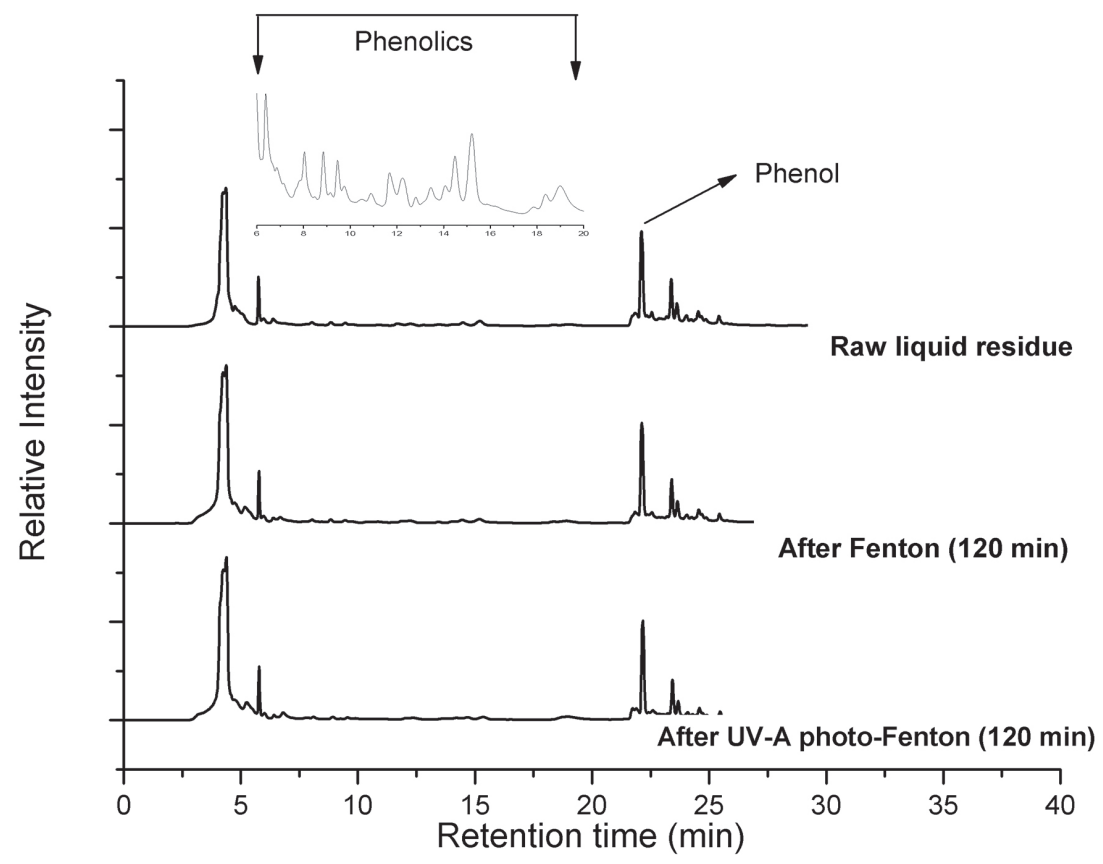

Figure 6. Chromatographic monitoring of the raw residue degradation by Fenton processes $\left(10 \mathrm{mg} \mathrm{L}^{-1} \mathrm{Fe}^{2+}, 100 \mathrm{mg} \mathrm{L}^{-1} \mathrm{H}_{2} \mathrm{O}_{2}\right.$, $\mathrm{pH}_{3}$ ).

$2,000 \mathrm{mg} \mathrm{L}^{-1}$, using the scrubber residue in the proportion of 1:9 (raw liquid residue:scrubber residue).

According to Garcia and Pargament, ${ }^{46}$ industrial residue reuse is a promising way to solve the water problem. It was decided to take another liquid residue, produced by the TELAB system in scrubbing operations. This residue is characterized by the low content of organic compounds and total phenolic forms, as suggested by the chromatographic profile (Figure 7). Moreover, the continuous addition of $\mathrm{H}_{2} \mathrm{O}_{2}$ was shown to be more efficient, ${ }^{47,48}$ due to the higher availability of hydroxyl radicals. ${ }^{49}$ Thus, experimental conditions were adjusted to higher concentrations of $\mathrm{H}_{2} \mathrm{O}_{2}$ and iron (200 and $15 \mathrm{mg} \mathrm{L}^{-1}$, respectively), and $\mathrm{H}_{2} \mathrm{O}_{2}$ was added every $20 \mathrm{~min}$.

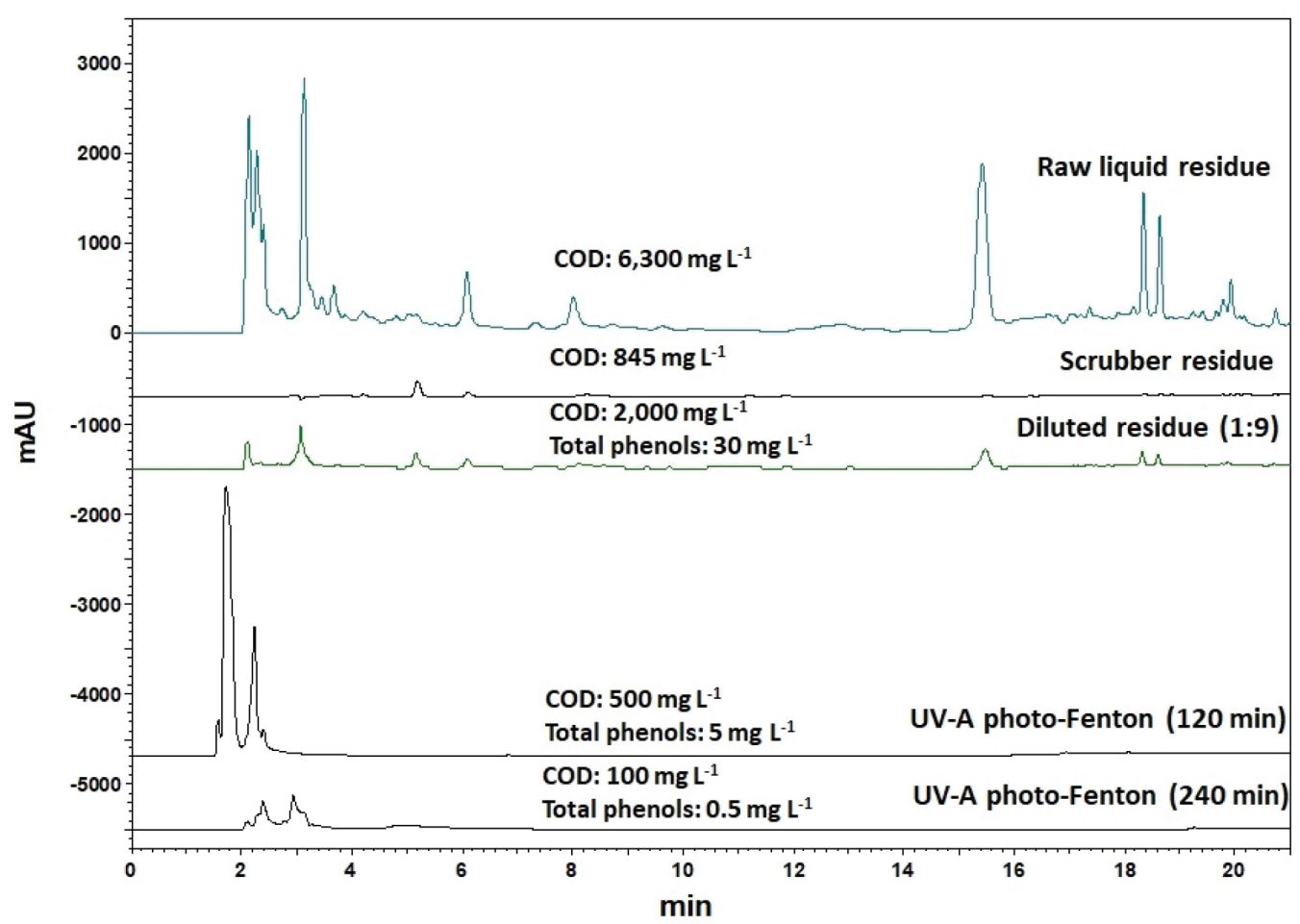

Figure 7. Chromatographic monitoring of the diluted residue (1:9) degradation by UVA photo-Fenton processes $\left(15 \mathrm{mg} \mathrm{L}^{-1} \mathrm{Fe}^{2+}, 200 \mathrm{mg} \mathrm{L}^{-1} \mathrm{H}_{2} \mathrm{O}_{2}\right.$, $\left.\mathrm{pH}_{3}\right)$. 
In these conditions, the photo-Fenton process applied for 120 min showed a COD reduction of approximately $75 \%$, and a removal of $80 \%$ of total phenols, as well as an almost complete removal of phenolic compounds, according to the chromatographic signals presented in Figure 7. New high-intense chromatographic signals were detected at lower retention times, probably associated with short-chain organic acids, arising from aromatic ring opening reactions. ${ }^{50}$ These species accumulate at the end of the process, because they are more resistant to the oxidative treatment. ${ }^{47}$ Corroborating with this argument, qualitative chromatographic studies allowed to suppose the formation of this short-chain organic acids, a fact that may explain the difficulties encountered in the removal of COD.

When the treatment was extended until $240 \mathrm{~min}$, it was possible to observe a reduction of COD of about $95 \%$, and a residual concentration of total phenolic forms of $0.5 \mathrm{mg} \mathrm{L}^{-1}$, which is in accordance with the CONAMA No. 430 (Brazilian legislation). ${ }^{37}$ The chromatographic signal associated with carboxylic acids was also significantly reduced, showing a residual signal that should be responsible for the remaining 5\% of COD. After the last treatment time (240 min), samples were characterized using chromatography for the quantification of BTEXs and phenolic compounds. The results (Table 2) show that the treatment made it possible to reduce the concentration of all monitored species, to values below the limit of quantification (LOQ), which corresponds to $4 \mu \mathrm{g} \mathrm{L}{ }^{-1}$ for toluene and $2 \mu \mathrm{g} \mathrm{L} \mathrm{L}^{-1}$ for benzene, ethylbenzene, and xylenes.

Toxicity assessments were performed using Daphnia magna and Vibrio fischeri as test organisms. Despite the high efficiency of the photo-Fenton process considering the degradation of phenolic species and petroleum hydrocarbons, the acute toxicity of the residue did not change during the treatment. These results might be related to the toxicity associated to other chemical species present in the raw liquid residue, such as ammoniacal nitrogen and metallic species, as well as carboxylic acids originated from the phenol oxidation.

The presented results showed that Fenton is a promising process to the treatment of petrochemical residue. However, considering the toxicity of the final treated residue, the association of Fenton with another treatment such as post-coagulation is worth testing, as discussed in the work of Saber et al..$^{42}$

\section{Conclusions}

The remediation of a liquid residue resulting from the thermal treatment of petrochemical residues by AOPs was a major challenge, particularly because of its high organic load (6,000 $\mathrm{mg} \mathrm{L}^{-1}$ of COD). Fenton processes, although demonstrating the best aqueous phenol degradation, were inefficient in the removal of organic matter and total phenolic species from the raw undiluted residue. Due to this limitation, the raw liquid residue was diluted with another liquid residue generated in the thermal process, achieving approximately $2,000 \mathrm{mg} \mathrm{L}^{-1}$ of COD. The diluted residue was applied in further studies, as well as higher $\mathrm{Fe}^{2+}$ and $\mathrm{H}_{2} \mathrm{O}_{2}$ concentrations and $\mathrm{H}_{2} \mathrm{O}_{2}$ addition every $20 \mathrm{~min}$. Photo-Fenton treatment, adjusted to these conditions, allowed the removal of approximately $95 \%$ of the COD load, and led to total residual phenol concentrations of about $0.5 \mathrm{mg} \mathrm{L}^{-1}$. At the same time, the concentration of BTEXs was reduced to values lower than the LOQ of the chromatographic technique. Finally, the photo-Fenton process represents an excellent alternative for the treatment of wastes containing refractory organic species.

\section{Acknowledgments}

The authors would like to acknowledge the funding of Albrecht, CNPq, CAPES and Fundação Araucária.

\section{References}

1. Diya'uddeen, B. H.; Daud, W. M. A. W.; Aziz, A. R. A.; Process Saf. Environ. Prot. 2011, 89, 95.

2. Godø, O. R.; Klungsøyr, J.; Meier, S.; Tenningen, E.; Purser, A.; Thomsen, L.; Mar. Pollut. Bull. 2014, 84, 236.

3. Xiong, W.; Bernesky, R.; Bechard, R.; Michaud, G.; Lang, J.; J. Sci. Total Environ. 2014, 487, 452.

4. Hu, G.; Li, J.; Zeng, G.; J. Hazard. Mater. 2013, 261, 470.

5. Kriipsalu, M.; Marques, M.; Maastik, A.; J. Mater. Cycles Waste Manage. 2008, 10, 79.

6. Xu, M.; Zhang, J.; Liu, H.; Zhao, H.; Li, W.; Fuel 2014, 126, 55 .

7. Liang, J.; Zhao, L.; Du, N.; Li, H.; Hou, W.; Sep. Purif. Technol. 2014, 130, 28.

8. Zhong, J.; Sun, X.; Wang, C.; Sep. Purif. Technol. 2003, $32,93$.

9. Yang, C.-L.; Sep. Purif. Technol. 2007, 54, 388.

10. Tahhan, R. A.; Ammari, T. G.; Goussous, S. J.; Al-Shdaifat, H. I.; Int. Biodeterior. Biodegrad. 2011, 65, 130.

11. Zhou, L.; Jiang, X.; Liu, J.; J. Hazard. Mater. 2009, 170, 175.

12. Pickler, A. C.; Gallo, L. F. P.; da Silva, C. A. D.; Albrecht, W.; Althoff, C. A.; BR PI 0400305-5 2004.

13. Gami, A. A.; Shukor, M. Y.; Khalil, K. A.; Dahalan, F. A.; Khalid, A.; Ahmad, S. A.; J. Environ. Microbiol. Toxicol. 2014, 2,11 .

14. Park, J. S.; Brown, M. T.; Han, T.; Aquat. Toxicol. 2012, 106107, 182. 
15. Kulkarni, S. J.; Tapre, R. W.; Patil, S. V.; Sawarkar, M. B.; Procedia Eng. 2013, 51, 300.

16. Yang, X.; Zou, R.; Huo, F.; Cai, D.; Xiao, D.; J. Hazard. Mater. 2009, 164, 367.

17. Chen, Y.; He, J.; Wang, Y. Q.; Kotsopoulos, T. A.; Kaparaju, P.; Zeng, R. J.; Biochem. Eng. J. 2016, 106, 19.

18. Lefèvre, S.; Boutin, O.; Ferrasse, J. H.; Malleret, L.; Faucherand, R.; Viand, A.; Chemosphere 2011, 84, 1208.

19. Singh, N.; Balomajumder, C.; J. Water Process Eng. 2016, 9 , 233.

20. Zhang, M.; Zhi, L.; Li, H.; Long, H.; Zhao, W.; Chem. Eng. J. 2013, 229, 99.

21. Araña, J.; Doña-Rodríguez, J. M.; Portillo-Carrizo, D.; Fernández-Rodríguez, C.; Pérez-Peña, J.; González Díaz, O.; Navío, J. A.; Macías, M.; Appl. Catal., B 2010, 100, 346.

22. Martins, R. C.; Rossi, A. F.; Quinta-Ferreira, R. M.; J. Hazard. Mater. 2010, 180, 716.

23. Babuponnusami, A.; Muthukumar, K.; J. Environ. Chem. Eng. 2014, 2, 557.

24. Grabowska, E.; Reszczyńska, J.; Zaleska, A.; J. Water Res. 2012, 46, 5453.

25. Suzuki, H.; Araki, S.; Yamamoto, H.; J. Water Process Eng. 2015, 7, 54.

26. Shukla, P. R.; Wang, S.; Ang, H. M.; Tade, M. O.; J. Sep. Purif. Technol. 2010, 70, 338.

27. Zhou, L.; Hu, J.; Zhong, H.; Li, X.; Chem. Eng. Res. Des. 2012, $90,377$.

28. Kušic, H.; Koprivanac, N.; Bozic, A. L.; Selanec, I.; J. Hazard. Mater. 2006, 136, 632.

29. Stets, S.; do Amaral, B.; Bach, L.; Nagata, N.; Peralta-Zamora, P. G.; Environ. Sci. Pollut. Res. 2017, 24, 6040.

30. American Public Health Association (APHA); Standard Methods for the Examination of Water and Wastewater, $21^{\mathrm{st}}$ ed.; APHA-AWWA-WEF: Washington DC, 2005.

31. US Environmental Protection Agency (US EPA); Method 8260B: Volatile Organic Compounds by Gas Chromatography/ Mass Spectrometry (GC/MS); US EPA: Washington, 1996.

32. US Environmental Protection Agency (US EPA); Method $8270 D$ Semivolatile Organic Compounds by Gas Chromatography/ Mass Spectrometry (GC/MS); US EPA: Washington, 1998.

33. US Environmental Protection Agency (US EPA); Method 3510C: Separatory Funnel Liquid-Liquid Extraction; US EPA: Washington, 1996.
34. ABNT NBR 12713: Aquatic Ecotoxicology - Acute Toxicity Test Method with Daphniaspp (Crustacea, Cladocera), ABNT: Rio de Janeiro, Brazil, 2009.

35. ABNT NBR 15411-3: Aquatic Ecotoxicology - Determination of Inhibitory Effect of Aqueous Samples on the Bioluminescence of Vibrio Fischeri (Luminescent Bacteria Essay), ABNT: Rio de Janeiro, Brazil, 2012.

36. Ahmed, S.; Rasul, M. G.; Martens, W. N.; Brown, R.; Hashib, M. A.; Desalination 2010, 261, 3 .

37. Ministério do Meio Ambiente, Conselho Nacional do Meio Ambiente (CONAMA); Resolução No. 430, de 13 de maio de 2011; Dispõe sobre as Condições e Padrões de Lançamento de Efluentes, Complementa e Altera a Resolução No. 357, de 17 de Março de 2005, do Conselho Nacional do Meio AmbienteCONAMA; Diário Oficial da União, Brasília, DF, No. 92, 16/05/2011, p. 89.

38. Chun, H.; Yizhong, W.; Hongxiao, T.; Chemosphere 2000, 41, 1205.

39. Matos, J.; Laine, J.; Herrmann, J.-M.; Appl. Catal., B 1998, 18 , 281.

40. Lathasree, S.; Rao, A.; Sivasankar, B.; Sadasivam, V.; Rengaraj, K.; J. Mol. Catal. A: Chem. 2004, 223, 101.

41. Montoya, J. F.; Atitar, M. F.; Bahnemann, D. W.; Peral, J.; Salvador, P.; J. Phys. Chem. C 2014, 118, 14276.

42. Saber, A.; Hasheminejad, H.; Taebi, A.; Ghaffari, G.; Appl. Water Sci. 2014, 4, 283.

43. Kakavandi, B.; Babaei, A. A.; RSC Adv. 2016, 6, 84999.

44. Gligorovski, S.; Sttrekowski, R.; Barbati, S.; Vione, D.; Chem. Rev. 2015, 115, 13051.

45. Malato, S.; Blanco, J.; Vidal, A.; Caceres, J.; Trincado, P.; Oliveira, J. C.; Vicent, M.; Chemosphere 2002, 47, 235.

46. Garcia, X.; Pargament, D.; Resour., Conserv. Recycl. 2015, 101, 154.

47. Hermosilla, D.; Cortijo, M.; Huang, C. P.; Chem. Eng. J. 2009 , $155,637$.

48. Zazo, J. A.; Casas, J. A.; Mohedano, A. F.; Gilaranz, M. A.; Rodriguez, J. J.; Environ. Sci. Technol. 2005, 39, 9295.

49. Zazo, J. A.; Casas, J. A.; Mohedano, A. F.; Rodriguez, J. J.; Water Res. 2009, 43, 4063.

50. Yalfani, M. S.; Contreras, S.; Medina, F.; Sueiras, J.; Appl. Catal., B 2009, 89, 519. 